\title{
AMPICILLIN SULBACTAM RESISTANCE PATTERN AS A FIRST-LINE DRUG IN CHILDREN
}

\author{
Oka Putrawan, IGAA Putri Sri Rejeki \\ Department of Clinical Pathology, Faculty of Medicine, Universitas Airlangga, Dr. Soetomo Hospital, Surabaya
}

\begin{abstract}
ABSTRAK
Infeksi sering terjadi pada anak yang menderita keganasan hematologi dan menyebabkan morbiditas dan mortalitas pada anak. Antibiotika yang diberikan harus berdasarkan hasil kultur dan uji kepekaan antibiotika. Ampicillin Sulbactam merupakan obat lini pertama pada anak yang mengalami infeksi. Penelitian ini bertujuan untuk mendapatkan gambaran pola resistensi Ampicillin Sulbactam dari kultur pada penderita anak yang dirawat inap di Ruangan Hemato - Onkologi Anak RSUD Dr. Soetomo Surabaya. Penelitian ini merupakan penelitian deskriptif. Data hasil kultur dan kepekaan terhadap Ampicillin Sulbactam diambil dari rekam medis penderita anak yang dirawat inap di Ruangan Hemato - Onkologi Anak RSUD Dr Soetomo Surabaya periode September 2012-Februari 2013. Didapatkan 342 pemeriksaan kultur dari 88 penderita (44 perempuan dan 44 laki-laki). Sebagian besar pasien berusia $<5$ th (58\%). Didapat pertumbuhan bakteri pada 83 kultur yaitu Escherichia coli,Burkholderia cepacia, dan Klebsiella oxytoca (Gram negatif) dan Coagulation Negatif Staphylococcus (CONS), Staphylococcus aureus, dan Staphylococcus saprophyticus (Gram positif) ditemukan pada kultur darah. Staphylococcus aureus (Gram positif) dan E.coli, Klebsiella pneumoniae, dan B.cepacia (Gram negatif) ditemukan pada kultur urine. Hasil tes kepekaan menunjukkan resistensi terhadap Ampicillin Sulbactam pada E.coli (69\%), Burkholderia cepacia (85\%), CONS (50\%), Staphylococcus aureus (25\%), K.pneumoniae (85\%), Klebsiella oxytoca (50\%), dan P.aeroginosa (67\%). Ditemukan resistensi ampicillin sulbactam di Ruangan Hemato-Onkologi Anak RSUD Dr. Soetomo pada E.coli (69\%), Burkholderia cepacia (85\%), CONS (50\%), Staphylococcus aureus (25\%), K.pneumoniae (85\%), Klebsiella oxytoca (50\%), dan P.aeroginosa (67\%). (FMI 2015;51:187-189)
\end{abstract}

Kata kunci: uji kepekaan antibiotika, kultur, resistensi, ampicillin sulbactam

\begin{abstract}
Infection often occurs in children with malignant hematology and causes morbidity and mortality. Antibiotics should be given based on the results of culture and antibiotic susceptibility test. Ampicillin Sulbactam is a first-line drug in children with infection. The purpose of this study was to obtain an objective overview of Ampicillin Sulbactam resistance patterns of culture in patients hospitalized in pediatric Hemato-Oncology Ward, Dr Soetomo Hospital, Surabaya. This was a descriptive study. Data on culture and susceptibility test result to Ampicillin Sulbactam were taken from medical records of those patients between September 2012 February 2013. There were 342 culture examinations in 88 patients (44 girls and 44 boys). Most of the children aged $<5$ years (58\%). Growth of bacterial cultures was obtained in 83 namely Escherichia coli, Burkholderia cepacia, and Klebsiella oxytoca (Gram-negative) and coagulation negative Staphylococcus (CONS), Staphylococcus aureus, and Staphylococcus saprophyticus (Gram-positive) were found in blood culture. Staphylococcus aureus (Gram positive) and E. coli, Klebsiella pneumoniae, and B.cepacia (Gram-negatif) were found in urine. The result of antibiotic susceptibility test culture showed resistance to Ampicillin Sulbactam in E. coli (69\%), Burkholderia cepacia (85\%), CONS (50\%), Staphylococcus aureus (25\%), K. pneumoniae (85\%), Klebsiella oxytoca (50\%), and P. aeroginosa (67\%). There was ampicillin sulbactam resistance in children hospitalized in pediatric Hemato-Oncology Ward, Dr Soetomo Hospital, Surabaya against E. coli (69\%), Burkholderia cepacia (85\%), CONS (50\%), Staphylococcus aureus (25\%), K.pneumoniae (85\%), and Klebsiella oxytoca (50\%), P. aeroginosa (67\%).(FMI 2015;51:187-189)
\end{abstract}

Keywords: antibiotic susceptibility test, culture, resistance, ampicillin sulbactam

Correspondence: Oka Putrawan, Department of Clinical Pathology, Faculty of Medicine, Universitas Airlangga, Dr. Soetomo Hospital, Jalan Prof. Dr. Moestopo 47, Surabaya 60131, Indonesia.

\section{INTRODUCTION}

Recently, patients with hematologic malignancies undergo frequent hospitalization. Malignancy patients have greater risk for an infection, even sepsis (Danai et al 2000). The source of infection can be derived from the transmission of microorganisms from other patients or from the patient's body itself. Patients with hematologic malignancies have generally already suffered from severe diseases and have been in immunocompromised circumstances (Patrick 2001, Waterer \& Wunderink 2001). Previous studies showed the longer a patient received antibiotic therapy, the more colony formation with antibiotic-resistant microbes emerged. For long term effect, their effectiveness against bacteria will lower, which finally results in resistance (Toltzis et al 1997). 
Data obtained by World Health Statistics based on data from Riset Kesehatan Dasar (Riskesdas) in the year 2007 showed that its mortality rate in Indonesia was still high at 36 deaths per 1.000 live births. Infectious diarrhea and pneumonia are the leading cause of death in infants. Infection is a source of morbidity and mortality in patients with malignancy. One of some causes of infections in patients with hematologic malignancies is neutropenia. Neutropenia is caused by bone marrow suppression due to malignant disease or postchemotherapy treatment. Antibiotic should be given appropriately to patients who have infection malignancy (HOMPEDIN 2006). Empirical based examination without knowing the pattern of bacterial data and antiobiotic susceptibility tests in antiobiotic treatment for the patients may lead to bacterial resistance to antibiotics (Favero et al 2004).

Tiflah \& Farida (2006) in their study at Dr. Kariadi Hospital obtained the most frequent types of bacteria, they were Enterococcus faecalis (40\%), Staphylococcus epidermidis (35\%), Escherichia coli (15\%), Staphylococcus aureus (5\%) and Pseudomonas aeruginosa (5\%). The study also found that most bacteria in blood cultures had undergone initial resistance to antibiotics used in Dr. Kariadi hospital, the amikacin, gentamycin and cefotaxime. The purposes of this study were to obtain an overview of Ampicillin Sulbactam resistance patterns in pediatric hemato-oncology ward at Dr. Soetomo Hospital and also to determine the sensitivity of Ampicillin Sulbactam against the growth of bacteria in culture.

\section{MATERIALS AND METHODS}

This was an observational descriptive study of patients hospitalized at pediatric hematology-oncology ward Dr. Soetomo Hospital from September to February 2013. Data on age, sex, diagnosis, culture, culture results, and antibiotic sensitivity test results were taken from medical records. Patients receiving ampicillin sulbactam antibiotic therapy were analyzed separately. Then, the bacterial resistance pattern was observed. Specimen were collected by taking the patient's blood as much as 1-5 $\mathrm{ml}$, then filled into the BACTEC bottles, incubated overnight at $37^{\circ} \mathrm{C}$. Bottles showing the growth of bacteria were then planted with blood agar, CLED, and McConkey media. Separated growing colonies were gram painted so they could be identified using biochemical tests, BD BBLTM Crystal TM Identification System and Automated Microbiology System PhoenixTM 100. The colony was also dissolved in PZ sterile turbidity of $0.5 \mathrm{McFarland}$, before antibiotic sensitivity test using disc diffusion and micro-dilution was done.

\section{RESULTS}

This study was observational, and the subjects were 88 patients; 44 male (50\%) and 44 female patients (50\%). Fifty one patients were at the age under 5 years old $( \pm$ $58 \%$ ) (Table 1).

Table 1. Distribution of patients in pediatric hematooncology ward in Dr. Soetomo hospital Surabaya

\begin{tabular}{lcc}
\hline \multicolumn{1}{c}{ Sex } & Amount & $\%$ \\
\hline Male & 44 & $50 \%$ \\
Female & 44 & $50 \%$ \\
\hline Total & 88 & $100 \%$ \\
\hline
\end{tabular}

Table 2. Distribution of patients based on age in pediatric hematooncology ward Dr. Soetomo Hospital Surabaya between September 2012 - February 2013

\begin{tabular}{lcc}
\hline \multicolumn{1}{c}{ Age } & Amount & $\%$ \\
\hline $0-<5$ years old & 51 & $58 \%$ \\
$5-<10$ years old & 24 & $27 \%$ \\
$10-15$ years old & 13 & $15 \%$ \\
\hline Total & 88 & $100 \%$ \\
\hline
\end{tabular}

Culture examination was done in 341 specimens. There were 18 growth culture out of 128 blood culture specimen, 36 growth culture out of 111 urine culture specimens, 25 growth culture out of 70 rectal swab culture specimens, 9 growth culture specimens out of 12 pus culture specimens, and 6 growth culture out of 13 feces culture specimens. Staphylococcus coagulase negative was a gram positive bacteria mostly found on blood culture $(27.7 \%)$, whereas most gram negative bacteria was Escherichia coli (11.1\%). Staphylococcus aureus was a gram postive bacteria in urine culture, but the gram positive bacteria mostly found was $E$. coli $(32.1 \%)$. Whereas, gram negative bacteria mostly found in urine culture was Pseudomas aeruginosa (62\%). E. coli was found in total rectal swab culture. The result of bacteria growth sensibility test in blood culture toward ampicillin sulbactam revealed E. coli (50\%), Klebsiella oxytica (100\%), Aeromonas veronii (100\%), Staphylococcus aureus (33.3\%), Staphylococcus sapropyticus $(100 \%)$, and CONS (50\%).

\section{DISCUSSION}

Klebsiella pneumonia (85.7\%), Burkholderia cefacia (85.5\%), Escherichia coli $(83.3 \%)$, Proteus mirabilis (100\%), and Acinetobacter (50\%) resistance was found as the result of bacterial sensibility test that grew on 
urine culture toward ampicillin sulbactam. Then the result of bacteria growth sensibility test in rectal swab culture toward ampicillin sulbactam only found $E$. coli (65\%). Fecal culture also revealed E. coli $(85.7 \%)$, and the result of bacteria growth sensibility test in pus culture toward ampicillin sulbactam revealed E. coli (100\%) and Pseudomonas aeruginosa (66.6\%). The result of antibiotic sensibility test toward gram negative bacteria and gram positive bacteria showed ampicillin sulbactam resistance on E. coli, Burkholderia cepacia, CONS, Staphylococcus aureus, K. pneumoniae, Klebsiella oxytoca, and P. Aeroginosa (Table 3).

Table 3. Bacteria resistance pattern toward ampicillin sulbactam in pediatric hemato-oncology wards, Dr. Soetomo Hospital, Surabaya.

\begin{tabular}{lcc}
\hline \multicolumn{1}{c}{ Bacteria Species } & Amount & $\%$ \\
\hline E.coli & 27 & $(69 \%)$ \\
Burkholderia cepacia & 6 & $(85 \%)$ \\
CONS & 2 & $(50 \%)$ \\
Staphylococcus aureus & 2 & $(25 \%)$ \\
K. pneumoniae & 6 & $(85 \%)$ \\
Klebsiella oxytoca & 1 & $(50 \%)$ \\
P.aeroginosa & 6 & $(67 \%)$ \\
\hline
\end{tabular}

\section{CONCLUSION}

E. coli, Burkholderia cepacia, CONS, Staphylococcus aureus, K. pneumoniae, Klebsiella oxytoca, P. aeroginosa are resistant to ampicillin sulbactam therapy at pediatric hemato-oncology wards, Dr. Soetomo Hospital, Surabaya.

\section{REFERENCES}

Danai PA, Moss M, Mannino DM, Martin GS (2006). The epidemiology of sepsis in patients with malignancy. Chest 129, 1432-1440

Del Favero A, Bucaneve G, Furno P (2004). Choice of empirical therapy and prophylaxis. Hematol J 5 Suppl 3, S53-58

Patrick CC (2001). Clinical Management of Infections in Immunocompromised Infants and Children, 1st ed., Philadelphia, Lippincott Williams \& Wilkins, p 584615

Ranuhardy D, Kurnianda J, Abdulmuthalib, Atmakusuma D, Kar AS, Acang N, Mediarty, Fadjari H, Tobing ML, Ashariati A, Fakhruddin, Darmayuda TG, Darmawan B, Harryanto A (2006). Panduan Tatalaksana Febril Neutropeni/Demam Neutropeni pada Pasien Kanker, Jakarta, Balai Penerbit Fakultas Kedokteran Universitas Indonesia, p 1-14

Tiflah, Farida H (2006). Bakteremia pada Neonatus: Hubungan Pola Kuman dan Kepekaannya terhadap Antibiotik Inisial serta Faktor Risikonya di Bangsal Bayi Risiko Tinggi (BBRT) RS Dr Kariadi Semarang Tahun 2004. Thesis. Universitas Diponegoro, Indonesia

Toltzis P, Yamashita T, Vilt L, Blumer JL (1997). Colonization with antibiotic-resistant gram-negative organisms in a pediatric intensive care unit. Crit Care Med 25, 538-544

Waterer GW, Wunderink RG (2001). Increasing threat of Gram-negative bacteria. Crit Care Med 29, N75-81 